\title{
Perancangan Aplikasi Pencarian Makna Motif Batik Menggunakan Metode Galil Seiferas
}

\author{
Lisa Wardani \\ Program Studi Teknik Informatika, STMIK Budi Darma, Medan, Indonesia \\ Email: lisawardani1501@gmail.com \\ Submitted 01-04-2020; Accepted 20-04-2020; Published 26-04-2020
}

\begin{abstract}
Abstrak
Bagi sebahagian orang batik hanyalah kain yang menjadi ciri khas dari Indonesia terkhusunya daerah pulau Jawa, namun tidak semua orang mengetahui bahwa setiap motif yang ada pada kain batik memiliki makna filosofi tersendiri dimana setiap makna tersebut erat kaitanya dengan kehidupan manusia. Sebagai masyarakat Indonesia ada baiknya kita mengetahui makna dibalik keindahan motif batik, namun tidak semua orang mengetahui nama motif batik dan dapat mencari makna nya di internet ataupun yang sering kita sebut browsing. Adapun solusi yang dapat dilakukan adalah dengan membuat suatu sistem pencarian makna motif batik berbasis android yang dapat memberikan kemudahan dalam melakukan pencarian makna motif batik. Pencarian dirancang dalam sebuah aplikasi yang membantu pencarian kata yaitu dengan menggunakan string matching yaitu algoritma pencarian Galil Seiferas. Dengan diterapkannya Algoritma Galil Seiferas pada sistem pencarian makna motif batik berbasis android ini, maka diharapkan dapat melakukan proses pencarian yang tepat dalam menampilkan makna motif batik serta lebih mudah dan cepat. Sistem yang dibangun tersebut juga sangat praktis karena berbasis android, sehingga dapat mempermudah pengguna mengakses dimana saja.
\end{abstract}

Kata Kunci: Andoid, Motif Batik, Algoritma Galil Seiferas.

\begin{abstract}
For some people batik is only a cloth that is a characteristic of Indonesia, especially the area of Java, but not everyone knows that every motif on batik cloth has its own philosophical meaning where each meaning is closely related to human life. As the people of Indonesia it helps us to know the meaning behind the beauty of batik motifs, but not everyone knows the name of batik motifs and can search for meaning on the internet or what we often call browsing. The solution that can be done is to create an Android-based batik meaning search system that can provide convenience in searching for the meaning of batik motifs. Search is designed in an application that helps word search using string matching, the Galil Seiferas search algorithm. With the implementation of Seiferas Galil Algorithm on the Androidbased batik meaning search system, it is expected to be able to carry out the right search process in displaying the meaning of batik motifs as well as being easier and faster. The system built is also very practical because it is based on Android, so it can make it easier for users to access anywhere.
\end{abstract}

Keywords: Andoid, Batik Motif, Seiferas Galil Algorithm.

\section{PENDAHULUAN}

Batik merupakan salah satu hasil kesenian yang mempunyai nilai seni tinggi dan telah menjadi bagian dari budaya Indonesia. UNESCO (United Nations Educational, Scientific and Cultural Organization) menetapkan batik sebagai warisan budaya milik Indonesia pada 2 Oktober 2009. Secara etimologis Batik mempunyai pengertian akhiran "tik" dalam kata "batik" berasal dari kata menitik atau menetes. Batik adalah kain yang dilukis menggunakan canting dan cairan lilin malam sehingga membentuk lukisan-lukisan bernilai seni tinggi diatas kain mori. Batik berasal dari kata amba dan tik yang merupakan bahasa jawa, yang artinya adalah menulis titik. Di Indonesia batik dikenal sejak zaman kerajaan Majapahit, kemudian menyebar ke kerajaan-kerajaan lain dan diturunkan kepada generasi raja-raja selanjutnya. Kesenian batik secara umum meluas di Indonesia serta secara khusus menyebar di pulau Jawa pada akhir abad ke-18 atau awal abad ke-19. Pada awalnya, batik yang dikenal adalah batik tulis. Batik tersebut dibuat dengan bahan dasar kain yang pada awalnya juga ditenun sendiri. Bahan-bahan pewarna yang digunakan adalah bahan pewarna yang diambil dari alam di daerah setempat (pohon mengkudu, tinggi, soga, nila, dan sebagainya).

Penelitian sebelumnya berjudul Aplikasi Pola Batik Menggunakan Metode Fraktal dan Algoritma 8 Wey Simetris [1] Batik dalam masyarakat Jawa memang tidak terlepas dari ajaran filsafat Jawa yang secara tersirat menjadi sentuhan yang indah dan mengandung makna filosofis pada setiap motifnya. Penampilan batik tradisional, baik dari segi motif maupun warnanya dapat menentukan darimana batik tersebut berasal. Seiring dengan berjalannya waktu motif batik juga berkembang sesuai dengan tempat, peristiwa yang menyertai serta perkembangan kebutuhan masyarakat. Sebagai csontoh motif Sidomukti, motif Parang, ataupun motif Kawung. Setiap motif batik yang tercipta senantiasa melambangkan simbol-simbol atau perlambang tertentu yang ingin digambarkan oleh pembatiknya. Motif batik memiliki sejarah penciptaan yang berkaitan dengan prilaku amalan yang dilakukan oleh sang pencipta motif tersebut. Para empu batik menghasilkan suatu rancangan motif batik tidak semata-mata hanya mementingkan keindahan guna meningkatkan stabilitas ekonomi melainkan melalui proses yang panjang. Para empu batik harus melalui proses pengendapan diri, meditasi untuk mendapatkan bisikan-bisikan dari hati nuraninya yang diibaratkan guna mendapatkan wahyu ataupun ide dan kreatifitas. Keindahan batik mengandung doa ataupun harapan dan pelajaran. Dengan mengetahui makna yang tersirat pada motif batik dan sejarah penciptaanya, maka diharapkan kita bisa memahami dan lebih apresiatif terhadap warisan budaya ini.

Motif batik yang diciptakan oleh seorang empu batik selalu memiliki makna kehidupan yang tersirat, senantiasa melambangkan simbol-simbol atau perlambang tertentu yang ingin digambarkan oleh seorang pembatik. Bagi sebagian masyarakat melihat batik hanya melalui ragam hias batik dan perpaduan warnanya saja, dimana sebenarnya disetiap motif batik memiliki makna yang sangat erat hubungannya dengan kehidupan. Sebagai masyarakat Indonesia sebaiknya kita turut serta menghargai apa yang menjadi kekayaan dari Negeri kita, walaupun batik yang sebagian besar berasal dari daerah Jawa 
tetapi tidak ada salah nya jika kita turut mengetahui makna di balik motif batik yang di ciptakan oleh para empu batik. Para generasi muda harus mempunyai rasa memiliki, rasa ingin mengetahui dan menjaga apa yang menjadi kekayaan budaya di negaranya terkhusus pada kesenian Batik. Hal ini dikarenakan Batik milik Indonesia bukan hanya milik Pulau Jawa jadi sudah selayaknya masyarakat Indonesia menjaga, menghargai dan mengetahui lebih banyak tentang batik yang merupakan salah satu kekayaan Indonesia yang diakui oleh dunia.

Algoritma Galil-Seiferas adalah algoritma yang arah pembacaan yang ditentukan oleh pemrogram, algoritma linier waktu pertama yang menggunakan jumlah ruang tambahan yang konstan. Algoritma ini membagi pattern y menjadi dua bagian yaitu y = y1 y2. Tahap preprocessing pada algoritma ini berguna untuk mendapatkan dekomposisi dari y1 dan y2 dari $\mathrm{x}$ yang mana y 2 memiliki paling banyak satu periode awalan, proses dekomposisi ini dinamakan perfect factorization.

Berdasarkan permasalahan diatas dilakukan penyelesaian masalah dengan perancangan aplikasi pencarian makna motif batik menggunakan algoritma pencocokan string (string matching) yaitu algoritma yang dapat mencari kata (pattern) dalam sebuah kalimat teks (string) untuk menemukan suatu kata dan menampilkan sebuah kata yang ditemukan dalam teks. Metode yang digunakan adalah metode Galil-Seiferas. Secara teknis pencarian dilakukan berdasarkan nama motif batik maka hasil pencarian akan menampilkan makna dari motif dan daerah asal dari motif batik tersebut, dimana provinsi Jawa Timur terdiri dari 29 kabupaten dan 9 kota yang masing-masing memiliki ciri khas motif batik.

\section{METODE PENELITIAN}

\subsection{String Matching}

String matching adalah proses pencarian semua kemunculan query yang selanjutnya disebut pattern ke dalam string yang lebih panjang (teks). Pattern dilambangkan dengan $\mathrm{x}=\mathrm{x}[0 . . \mathrm{m}-1]$ dan panjangnya adalah $\mathrm{m}$. Teks dilambangkan dengan $\mathrm{y}=\mathrm{y}$ [0..n-1] dan panjangnya adalah n. Kedua string terdiri dari sekumpulan karakter yang disebut alfabet yang dilambangkan dengan $\sum$ (sigma) dan mempunyai ukuran $\sigma$ (tao). String matching dibagi menjadi dua, yakni exact matching dan heuristic atau statistical matching. [10]

\subsection{Batik}

Batik merupakan salah satu warisan budaya nusantara yang unik dan memiliki makna filosofis yang tinggi. Batik merupakan rangkaian kata mbat dan tik. Mbat dalam Bahasa Jawa dapat diartikan sebagai ngembat atau melempar berkali-kali, sedangkan tik berasal dari kata titik. Jadi, batik memiliki arti menghubungkan titik-titik menjadi gambar tertentu pada kain yang luas atau lebar. Batik juga mempunyai pengertian segala sesuatu yang berhubungan dengan membuat titik-titik tertentu pada kain mori. [7] Dalam masyarakat keraton, batik batik merupakan suatu simbol, bahkan ada aturan tentang motif tertentu yang rakyat dilarang untuk mengenakannya. Corak ini hanya boleh digunakan pada kalangan keluarga raja.

\subsection{Algoritma Galil-Seiferas}

Algoritma Galil Seiferas adalah algoritma yang ditemukan oleh Galil dan Seiferas, algoritma ini merupakan suatu bentuk algoritma pencarian string yang me- lakukan pemeriksaan dari kiri ke kanan dan dari kanan ke kiri yang menggunakan Konstanta k oleh Galil dan Seiferas dinyatakan bernilai 4. Karakteristik algoritma dua arah adalah bahwa pola $x$ yang akan diperiksa dibagi menjadi dua bagian yaitu $(y 1)$ dan (y2). Sebelum melakukan pencarian Algoritma Galil-Seiferas terlebih dahulu akan melakukan fase preprocessing pada pattern. Fase preprocessing berguna untuk mendapatkan dekomposisi ( $y 1)$ dan $(y 2)$, proses dekomposisi dinamkan faktorisasi sempurna (perfect factorization). Faktorisasi sempurna berguna untuk poses pencocokan pattern dengan teks. Adapun langkah-langkah fase preprocessing Algoritma Galil Seiferas adalah sebagai berikut:

1. Pembagian pattern menjadi dua bagian, yaitu bagian sebelah kiri dan kanan. Bagian kiri di variabelkan dengan ( $y 1)$ dan bagian kanan di variabelkan dengan (y2).

2. Untuk menentukan $(y l)$, akan dilakukan dengan menemukan awalan $(y l)$ yang cocok dengan akhiran $(y l)$ dan sisanya akan menjadi (y2).

Sedangkan aturan pada proses pencarian string adalah :

1. Algoritma Galil Seiferas mencocokkan pattern dari awal teks.

2. Dari bagian kanan pattern dari sebelah kiri lalu dilanjutkan pada bagian kiri pattern dari sebelah kanan, algoritma ini akan mencocokan karakter pattern dengan karakter teks yang bersesuaian, sampai salah satu kondisi berikut terpenuhi:

a. Karakter di pattern yang di bandingkan tidak cocok

b. Semua karakter di pattern cocok. Selanjutnya algoritma memberitahukan penemuan kondisi ini.

3. Kedua bagian pola diproses secara bergantian, yaitu diawali dengan pemeriksaan pola bagian kanan $(y l)$ dari arah kiri ke kanan, lalu dilanjutkan pattern (y2) dari arah kanan ke kiri..

Pada pencarian kedua akan dilakukan pemeriksaan pada bagian kiri (y2) dari arah kanan ke kiri, menggeser pattern sebesar satu ke kanan jika tidak terdapat kecocokan antara pattern dan teks, menggeser pattern sebesar jumlah pattern (yl) dan (y2) dikurang satu jika terjadi kecocokan di pattern (y1) atau (y2), dan mengulang langkah ke-2 sampai pattern berada di ujung teks. [11] 


\section{HASIL DAN PEMBAHASAN}

Pencarian makna motif batik akan dilakukan dengan memasukan teks (string) kedalam kolom pencarian motif batik. String berupa nama motif batik beserta pola batik yang berasal dari provinsi Jawa Timur. Penggunaan pencarian motif batik sebelumnya hanya memasukkan nama dari motif batik saja lalu menampilkan makna dari motif batik tersebut sehingga setiap orang yang mempunyai keinginan untuk mengetahui makna dari suatu batik harus terlebih dahulu mengetahui nama dari batik tersebut, tetapi tidak semua orang mengetahui nama motif batik yang ingin dicarinya bahkan kebanyakan orang mengenakan baju batik tidak mengetahui makna dari motif batik yang dikenakannya, hanya melihat dari segi keindahan nya saja ataupun berdasarkan kesukaan masing-masing orang. Oleh karena itu aplikasi ini dibuat agar bisa melakukan pencarian makna motif batik berdasarkan nama motif batik ataupun memasukkan pola batik yang berasal dari Jawa Timur.

Proses pencarian makna motif batik akan dilakukan dengan mencocokkan string berupa nama ataupun pola batik dengan data yang ada pada database. Proses pencarian menggunakan algoritma Galil Seiferas sebagai solusi dalam pencarian makna motif batik dimana arah pencarian ditentukan oleh pemrogram (in a specific order). Fase preprocessing sebagai langkah awal dari algoritma Galil Seiferas terdiri dalam menentukan dekomposisi variabel $u v$ dari pattern. Dimana variabel $u$ mencocokan pattern ke kiri dan variabel $v$ mencocokan pattern ke sebelah kanan, yang berfungsi sebagai acuan dari pencarian. Algoritma Galil Seiferas akan mencocokan pattern dengan teks berdasarkan fase preprocessing dalam waktu $\mathrm{o}(\mathrm{m})$ dan kompleksitas ruang konstan dan fase pencarian dalam o(n) kompleksitas waktu. Oleh karena itu, pada pencarian makna motif batik diharapkan algoritma Galil Seiferas dapat menyelesaikan masalah tersebut, dimana dalam algoritma string matching penyajian makna motif batik lebih sedikit karena adanya proses pengecekan berdasarkan pattern pola motif batik.

Hasil dari pencarian menampilkan nama motif batik, daerah asal motif batik yang merupakan daerah di Provinsi Jawa Timur, gambar motif batik dan makna motif batik. Aplikasi yang dibangun berbasis android dengan platform yang digunakan adalah Eclipse Juno. Eclipse membutuhkan android SDK (software development kit) sebagai alat bantu dan API (application programming interface) dalam mengembangkan aplikasi pada platform android menggunakan bahasa pemrograman Java.

\subsection{Penerapan Algoritma Galil-Seiferas}

Fase preprocessing Algoritma Galil Seiferas.

1. Langkah pertama pada fase prepocessing yaitu pembagian pattern menjadi dua bagian, yaitu bagian sebelah kiri dan kanan.

$\operatorname{Pattern}(x)=$ DAHANA

$\operatorname{Teks}(y)=$ PARANG DAHANA MUNGAL

Tabel 1. Inisialisasi Algoritma Galil Seiferas

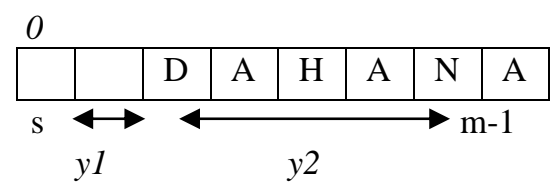

$\mathrm{p}=0 \quad \mathrm{q}=0 \quad \mathrm{q} 1=1 \quad \mathrm{~s}=0 \quad \mathrm{p} 1=5$

Poses awal yang dilakukan adalah menginisialisasi variabel yaitu p,q,s untuk memasukan pattern di dalam teks pencarian sebelum proses dimulai. P1 merupakan jumlah pattern yang akan diberikan. Q1 merupakan jumlah kemunculan yang mirip dengan pattern di dalam string. Setelah dilakukan fase preprocessing lalu dilakukan proses pencarian berdasarkan aturan yang terdapat pada algoritma tersebut. Berikut ini adalah contoh proses pencarian Algoritma Galil Seiferas:

Tabel 2. Pencarian Kata

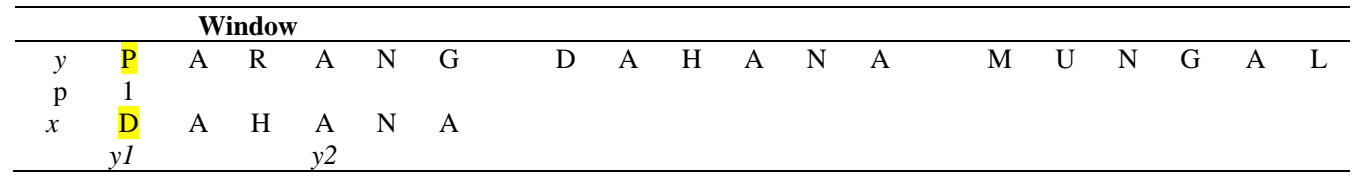

2. Langkah perama pada proses pencarian yaitu algoritma Galil Seiferas mencocokan pattern dari awal teks. Lakukan pencocokan pada $y 1$ dari arah kiri dan tidak ditemukan kecocokan, lakukan pencocokan pada y2 dari arah kanan dan tidak ditemukan kecocokan., geser satu kali ke kanan.

Tabel 3. Langkah kedua pencarian dengan Algoritma Galil Seiferas

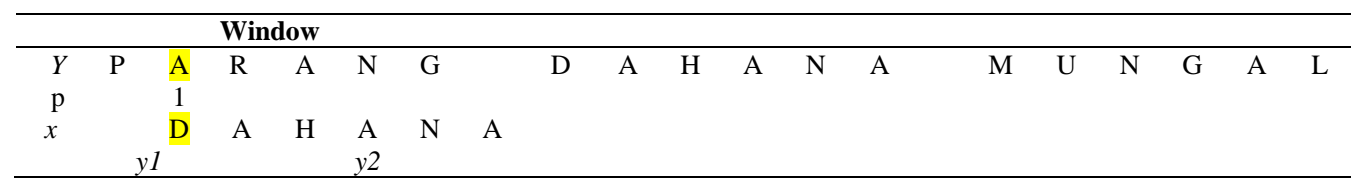

3. Langkah kedua, pencarian dilakukan dari bagian kanan lalu dilanjutkan pada bagian kiri pattern. Lakukan pencocokan pada $y 1$ dari arah kiri dan tidak ditemukan kecocokan, lakukan pencocokan pada y2 dari arah kanan dan tidak ditemukan kecocokan., geser satu kali ke kanan. 
Tabel 4. Langkah ketiga pencarian dengan Algoritma Galil Seiferas

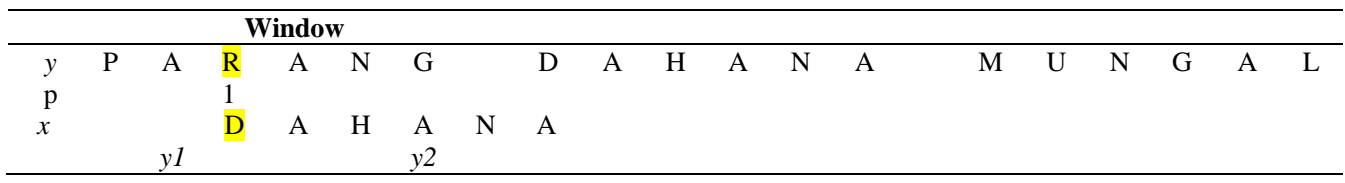

4. Langkah ketiga, kedua bagian pattern diproses secara bergantian, yaitu diawali dengan pemeriksaan pattern bagian kanan (yl) lalu pattern kiri (y2). Lakukan pencocokan pada yl dari arah kiri dan tidak ditemukan kecocokan, lakukan pencocokan pada y2 dari arah kanan dan tidak ditemukan kecocokan., geser satu kali ke kanan.

Tabel 5. Langkah keempat pencarian dengan Algoritma Galil Seiferas

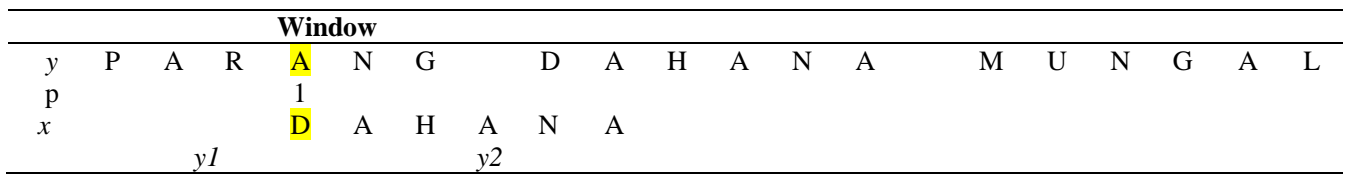

5. Langkah keempat, menggeser pattern sebesar satu langkah ke kanan jika tidak terdapat kecocokan antara pattern dan teks. Lakukan pencocokan pada yl dari arah kiri dan tidak ditemukan kecocokan, lakukan pencocokan pada y2 dari arah kanan dan tidak ditemukan kecocokan., geser satu kali ke kanan.

Tabel 6. Langkah kelima pencarian dengan Algoritma Galil Seiferas

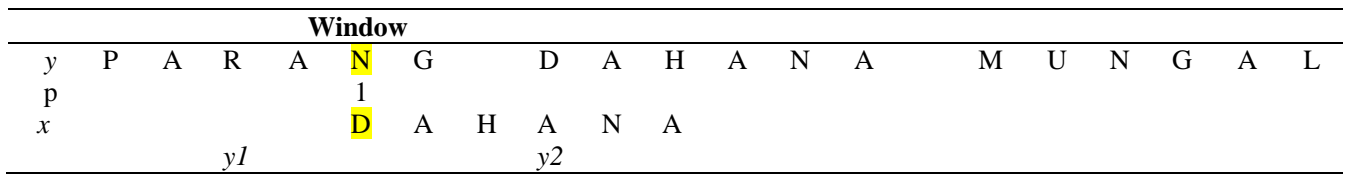

Lakukan pencocokan pada $y 1$ dari arah kiri dan tidak ditemukan kecocokan, lakukan pencocokan pada y2 dari arah kanan dan tidak ditemukan kecocokan., geser satu kali ke kanan.

Tabel 7. Langkah keenam pencarian dengan Algoritma Galil Seiferas

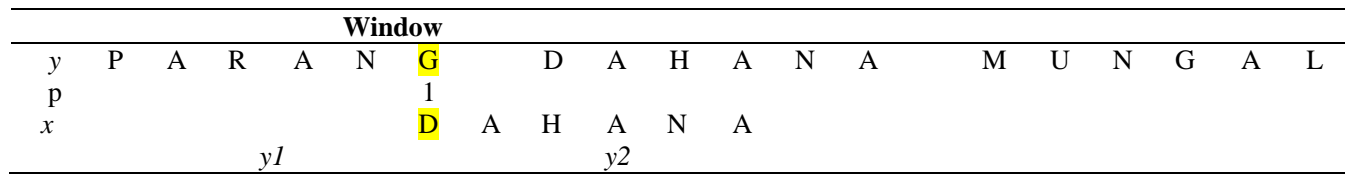

Lakukan pencocokan pada $y 1$ dari arah kiri dan tidak ditemukan kecocokan, lakukan pencocokan pada y2 dari arah kanan dan tidak ditemukan kecocokan., geser satu kali ke kanan.

Tabel 8. Langkah ketujuh pencarian dengan Algoritma Galil Seiferas

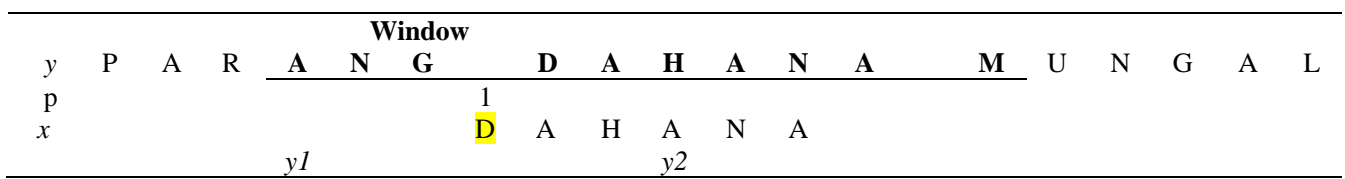

Lakukan pencocokan pada yl dari arah kiri dan tidak ditemukan kecocokan, lakukan pencocokan pada y2 dari arah kanan dan tidak ditemukan kecocokan., geser satu kali ke kanan.

Tabel 9. Langkah kedelapan pencarian dengan Algoritma Galil Seiferas

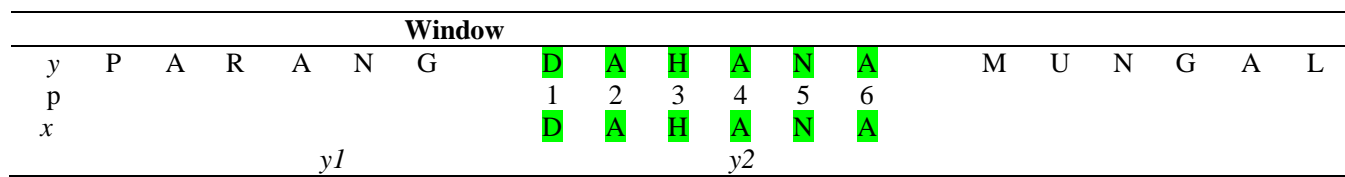

Pattern ditemukan. Pada langkah kedelapan telah ditemukan kecocokan antara pattern dan teks. Maka akan tampil pada hasil pencarian nama motif batik, asal daerah, gambar motif batik, dan maknanya.

\section{KESIMPULAN}

Berdasarkan hasil analisa bab-bab sebelumnya maka penulis dapat menarik sebuah kesimpulan, dimana kesimpulan ini sekiranya dapat berguna bagi pembaca, sehingga penulisan skripsi ini dapat lebih bermanfaat. Adapun kesimpulankesimpulan tersebut antara lain sebagai berikut : 
1. Pencarian makna motif batik menggunakan algoritma Galil Seiferas. Dalam algoritma pencarian string, pencarian dilakukan dengan memasukan pattern dan teks. Pada pencarian makna motif batik pencarian dilakukan dengan memasukan pattern berupa nama motif batik atau pola batik.

2. Algoritma Galil Seiferas dapat diimplementasikan sebagai solusi dam pencarian makna motif batik, dikarenakan algoritma Galil Seiferas mempunyai arah pencarian yang ditentukan secara spesifik (specific order) sehingga lebih efektif dalan pecarian pattern yang lebih panjang.

3. Aplikasi pencarian makna motif batik telah selesai dibangun menggunakan Software Eclipse Juno sebagai editor, Software Development Kit (SDK) sebagai platform dan dapat dijalankan pada perangkat mobile dengan sistem operasi android 7.1 Nougat.

\section{REFERENCES}

[1] F. Dan and A. Lingkaran, “APLIKASI POLA BATIK MENGGUNAKAN METODE Abstrak,” vol. 10, pp. 1-9, 2014.

[2] Al-Bahra bin Ladjamudin, Analisis dan Desain Sistem Informasi. Yogyakarta: Graha Ilmu, 2005.

[3] Jogiyanto Hartono, Analis dan Desain. 2004: Andi Offset, 2004

[4] L. L. Rinaldi Munir, Algoritma dan Pemrograman Dalam Bahasa Pascal, C, dan C++. INFORMATIKA, 2016.

[5] Mansoer Patteda, Semantik Leksikal. Jakarta: Rineka Cipta, 2001.

[6] Sinung27, "Pengertian Motif dan Jenisnya," 2016.

[7] Ari wulandari, Batik Nusantara. Yogyakarta: C.V ANDI OFFSET, 2011.

[8] Oemar Hamalik, Proes Belajar Mengajar. Jakarta: Bumi Aksara, 2001.

[9] Rosady Ruslan, Metode Penelitian PR dan Komunikasi. Jakarta, 2003.

[10] E. Yeni Anistyasari, dan Rahimi Fitri Riyanto Sorno, Semantic Search. Yogyakarta: Andi Offset, 2012.

[11] T. E. S. Searching, “Algorithmica," 1995.

[12] Rosa A.S dan M. Shalahuddin, Rekayasa Perangkat Lunak. Bandung: Informatika Bandung, 2014.

[13] Rini Agustina dan Dodit Suprianto, Pemrograman Aplikasi Android. Medikim, 2012.

[14] Irawan, membuat Aplikasi Android untuk Orang Awam. Palembang, 2012.

[15] Nazaruddin Safaat, Pemograman Aplikasi Mobile Smartphone dan Tablet Pc. Bandung: Informatika Bandung, 2015.

[16] Janner Simarmata, Perancangan Basis Data. Yogyakarta: Andi Offset, 2007.

[17] Mark L. Marphy, Beginning Android. USA, 2010.

[18] A. K. Dr. Yusak Ansori, Keeksotisan Batik Jawa Timur. Jakarta: PT. ELEX MEDIA KOMPUTINDO, 2011.

[19] A. A. B. Ginting and D. P. Utomo, "PERANCANGAN APLIKASI CATALOG WISATA DI SUMATERA UTARA MENGGUNAKAN ALGORITMA RABIN-KARP," KOMIK (Konferensi Nasional Teknologi Informasi dan Komputer), vol. 3, no. 1, pp. 57-63, 2019. 